\title{
Designing Physics Learning Based on Local Potential During New Normal Era
}

\author{
Indah Slamet Budiarti ${ }^{*}$, Winarti ${ }^{2}$, Viyanti ${ }^{3}$
}

${ }^{1}$ Department of Physics Education, Education and Teacher Training Faculty, Universitas Cenderawasih, Indonesia ${ }^{2}$ Department of Physics Education, Education and Teacher Training Faculty, UIN Sunan Kalijjaga Yogyakarta, Indonesia

${ }^{3}$ Department of Physics Education, Education and Teacher Training Faculty, Universitas Lampung, Indonesia

*Correspondence to: indah_budiarti@yahoo.com

\begin{abstract}
This research explored and looked forward to the competencies and objectives of the feasibility of learning designs needed for the post-quarantine era of the COVID-19 pandemic in Indonesia, especially in Papua. The research method used in our study is qualitative which focuses on structural analysis to answer problems in the research found through preliminary studies. Our research sites are located in several educational institutions in Papua. The study population was all students at the elementary, junior high, high school and university levels in Papua, Indonesia. We used a sampling method in the form of a purposive sampling technique. The samples were three academic institutions; SMP N 5 Jayapura, SMA Pembangunan V Yappis, and Universitas Cenderawasih. Research instruments for collecting data were in the form of interview sheets, observation sheets, and questionnaires related to physics learning in the new normal era. The results of the study found that the physics learning design based on local potential in the new normal era can be an alternative for teaching physics concepts contextually. Students can observe the surrounding environment related to local customary culture which is indigenous science and educators represent the report in the form of a connection between the concept of science and local culture.
\end{abstract}

Keywords: local potential; new normal; physics learning

Recommended citation: Budiarti, I. S., Winarti, \& Viyanti. (2022). Designing Physics Learning Based on Local Potential During New Normal Era. Journal of Innovation in Educational and Cultural Research, 3(1), 30-40.

\section{INTRODUCTION}

One of the causes of the low learning achievement of students in physics is that the learning media used by teachers do not attract the attention of students (Kaya \& Elster, 2018). The learning media generally used by students in the physics learning process are textbooks (Rianti et al., 2020). The obstacles that exist in learning resources, approaches, methods, media, and physical learning models affect the motivation of students in studying physics (Annisa, Lesmono, \& Yushardi, 2020). Physics learning designs that are used and chosen appropriately can generate motivation in learning activities and have a positive influence on the psychology of students. The use of learning designs appropriately can help the effectiveness of the learning process because information can be presented in a more attractive and reliable manner.

Students are required to adapt to the digital learning environment through a combination of offline and online learning during new normal era (Fitriyani et al., 2020; Sadikin \& Hamidah, 2020). Therefore the research regarding on how online learning shapes the cognitive and social presence was conducted to determine the blended environment (Chang-Tik, 2020). Other study found the community of inquiry framework due to the rapid growth of online learning (Miller \& Edward, 2020) and supported by the institutional perspectives (Vanleeuwen \& Belikov, 2020). Several areas in Indonesia are still in the red zone of pandemic transmission so that face-to-face learning in class is not possible (Atiqoh, 2020; Bohmer et al., 2020). This condition makes educators trying to compile teaching materials so that students still have good attention to join the class of physics through online learning (Atiqoh, 2020; Bohmer et al., 2020). The educators need a new learning design to overcome the problems related to online learning during the new normal era, so that educators remain optimal in conveying physics concepts and students still have a good level of understanding of physics concepts.

Several kinds of tools in physics learning design are learning media and resources (Akmam et al., 2018; Sulistijo et al., 2017; Trisniarti et al., 2020). Physics learning in urban areas is often equipped with practical equipment both in demonstrations and experiments to support learning (Handhika, et al., 2020). However, areas that have difficulty having access to technology are absolutely "forced" to use devices around the student's residence so that physics learning concepts can be conveyed properly (Budiarti, 2017; Handhika 
et $a l_{.}, 2020$ ). The task of educators in rural areas is to design science learning, especially physics, so that it becomes contextual learning even though it does not use standard teaching aids in laboratories located in urban schools (Budiarti, et al., 2020).

Several researchers also tried to formulate the learning media, learning method, and learning approach during pandemic. One of the researchers determined the implementation of fish species diversity books through online learning. The implementation is effective in increasing student learning motivation, but it is less effective in motivating desires, appreciation, and not being attractive enough. The obstacles of online learning at Kampar High School include internet network facilities and field practicum during the covid-19 period (Yustina et al., 2020). Yet, the research done did not focus on the new normal era. Other study found that while students preferred face-to-face, physical teaching, they were able to adapt to the new norm of elearning. More than $60 \%$ of the students agreed that pre-recorded lectures and viewing videos of practical sessions, plus answering short questions, were beneficial. But, the technical problems such as the lack of internet connection becomes new problem (Azlan et al., 2020).

It leads to the needs of local potential from certain area around the country. Considering that learning should be meaningful and constructing, environment surrounding students can be addressed to become one of learning source. It can alienate the problems related to internet connection. Hybrid learning using contextual learning resource (offline) and internet classroom when there is internet connection (online) ca $\mathrm{n}$ be combined (Singh \& Hussain, 2020). The assessment of surrounding area to discover physics concepts can be done through multiple-criteria decision making approach (Gong et al., 2021). Teachers can obtain students from their very house to determine the students' learning process. Local potential is not only directing us to the solution of learning afar during new normal, but also integrating the contextual learning with the scientific concepts so that students can apply their findings directly toward their environment.

The local potential that exists in each region in Indonesia can be used as a means of contextual learning (Ibe \& Nwosu, 2017). Several studies that have been carried out by previous researchers have found that local potential or local wisdom can improve students' learning outcomes (Risdianto et al., 2020; Sudarmin et al., 2018), improve conceptual understanding in students (Atmojo, 2015; Dwianto et al., 2017), and has a good effect on building concepts that are long term memory in students (Budiarti et al., 2020; Budiarti, et al., 2017). However, on the other hand, there are several studies that have contradictory results by getting results that local potential does not contribute to improving learning outcomes (Fitriah, 2019), conceptual understanding (Prasetyono \& Rakhmawati, 2019), and long term memory of physics concepts in students (Indrawardana, 2013). The local potential in each area is different and educators must use it as creatively as possible to become a structured, constructive, and accountable physics lesson for its validity against physics concepts that scientists have discovered previously; not just matching material with local culture so that students are not skeptical.

Based on the research background explained, we conducted research that focused on designing physics learning based on local potential during new normal era after the COVID-19 pandemic quarantine in Indonesia. Our research sites was located in Jayapura, Papua. We conducted a preliminary study to obtain data on the learning process currently taking place in school institutions as a sample. As a follow-up, we proposed a physics learning design to answer the challenges being faced by educators in Jayapura, Papua, in the new normal era. It is expected that this research can be a new beginning for further studies that discuss new learning designs during new normal era for other subjects in rural areas.

\section{METHODS}

\section{Research Approach}

The research method used in our study is qualitative. The qualitative approach focuses on structural analysis to answer problems in research found through preliminary studies (Suherman, 2014). Our research sites are located in several educational institutions and schools in Papua from the junior high school, high school, and university levels. This research was conducted from August to November 2020 for four months during the first semester. This research includes three stages as follows: 1) The preparation stage, namely a preliminary study and 2) The research stage, namely the development of physics learning design in the new normal era (Utama, 2017).

\section{Participants}

The study population was all students at the elementary, junior high school, high school and university levels in Jayapura, Papua, Indonesia. The selection of informants is very relevant for educational research and learning because people are constantly seeking knowledge and information related to new and adaptive 
learning designs in accordance with the demands of 21st century skills competencies (Guarte \& Barrios, 2006). In this study the competence and learning objectives were adjusted to the new normal era. We chose the purposive sampling technique because of the need for research to find deep and systematic problems in learning science and physics in the new normal era after the COVID-19 pandemic quarantine era in Jayapura, Papua, which was carried out at various levels of education (Tongco, 2007). There were three educational institutions as the research sample, namely SMP N 5 Jayapura, SMA Pembangunan V Yappis, and Universitas Cendrawasih. The physics educator respondents who became the sample in this study were 40 people.

\section{Instruments}

The instruments used during the pilot study were observation sheet on teaching and learning process during the new normal era in covid-19 pandemic widespread, interview sheets, and documentation. We collected the data from several academic institutions to determine the fundamental problems happened during the physics learning course. After that, the instruments used during the main research were students' questionnaires as respondents related to physics learning, interview sheets for teachers as research subjects, and observation sheets to observe direct learning in physics classes or courses during the new normal era.

\section{Data Collecting Technique}

Initial research or pilot study was carried out with field observations for a preliminary study through reference review, unstructured interviews, and document review at related institution. At the junior high school level, we chose SMP N 5 Jayapura. At the high school level, our research location was located at SMA Pembangunan V Yappis. At the university level, Universitas Cendrawasih is the destination of our research location. We explored problems related to science learning (at the junior high school level) and physics learning (at the high school and university levels) in the new normal era. Data collecting techniques during the main research were direct observation, interviews for teachers, and questionnaires for students.

\section{Data Analysis Technique}

Data collected then were analyzed using triangulation method to determine the needs in physics learning during new normal when the pandemic covid-19 still emerges in Indonesia (Patton, 2014). Results from questionnaires ranged from low, sufficient, and high. There were six indicators of physics learning during new normal era. The indicators were adapted and modified from Alsmadi et al. (2021). Thus, the effective formulation of physics learning using online and offline method can be applied.

\section{RESULT AND DISCUSSION}

\section{Results on Questionnaires of Physics Learning During New Normal Era}

The questionnaire was used as a data collection tool to determine the tendency of educators in carrying out physics learning in the new normal era. The results of the questionnaire that have been collected can be seen in Table 1.

Table 1. Results on Questionnaires of Physics Learning During New Normal Era

\begin{tabular}{|c|c|c|c|c|c|c|}
\hline \multirow{2}{*}{ Indicator } & \multicolumn{2}{|c|}{ Low } & \multicolumn{2}{|c|}{ Sufficient } & \multicolumn{2}{|c|}{ High } \\
\hline & $\mathrm{n}$ & $\%$ & $\mathrm{n}$ & $\%$ & $\mathrm{n}$ & $\%$ \\
\hline The effectiveness of learning physics during new normal era & 24 & 60.0 & 10 & 25.0 & 6 & 15.0 \\
\hline The efficiency of physics learning strategies used in the new normal era & 20 & 50.0 & 11 & 27.5 & 9 & 22.5 \\
\hline $\begin{array}{l}\text { The difficulty level of the obstacles experienced in learning physics in the } \\
\text { new normal era }\end{array}$ & 9 & 22.5 & 25 & 62.5 & 6 & 15.0 \\
\hline $\begin{array}{l}\text { The level of problem solving that appears in learning physics in the new } \\
\text { normal era }\end{array}$ & 9 & 22.5 & 20 & 50.0 & 11 & 27.5 \\
\hline The enthusiasm of students during physics learning in the new normal era & 3 & 7.5 & 9 & 22.5 & 28 & 70.0 \\
\hline $\begin{array}{l}\text { Students' understanding of physics concepts during physics learning in the } \\
\text { new normal era }\end{array}$ & 10 & 25.0 & 21 & 52.5 & 9 & 22.5 \\
\hline
\end{tabular}

Based on Table 1, it can be seen that the indicators in questionnaire number five have a high achievement value from the respondents (70\%). Students still have high enthusiasm for learning physics during the new normal era. Only a few students are not enthusiastic about learning physics during the new normal. The lowest achievement values for physics learning indicators are in the first and second questionnaire indicators. The number one indicator point is the effectiveness of learning physics in the new 
normal era. A total of 24 educators filled the "low" choice category for this point. Only six educators answered that the effectiveness of physics learning in the new normal era was in the "high" category. The number two indicator point is the efficiency of choosing a physics learning strategy. A total of 20 educators answered "low", 10 educators answered "sufficient", and 6 educators answered "high". The third, fourth, and sixth indicators have a normal distribution pattern in the questionnaire answers. On these three indicators, most respondents answered in the "sufficient" category with details of $62.5 \%$ (indicator 3), 50\% (indicator 4), and $52.5 \%$ (indicator 6). The various results on this questionnaire were analyzed in the next sub section.

\section{Results on Interview Results of Physics Learning During New Normal Era}

Interviews were conducted with respondents from SMP N 5 Jayapura, SMA Pembangunan V Yappis, and Universitas Cendrawasih University regarding physics learning during the new normal era. Based on respondents' answers, there are two categories of physics learning strategies in the new normal era, namely: 1) online learning strategies and 2) online and offline learning strategies.The educator from SMP N 5 Jayapura explained that the school where she taught physics is now using the Jitsi Meet application for online learning.

"Learning in this pandemic era is online and offline learning. At SMP N 5 Jayapura, not all students have internet access. There are several categories of access here: students who don't have cellphones, students who have cellphones but not Androids, students who have Android phones but don't have an internet data plan, and students who have Android phones and internet data plans. We use Jitsi Meet for online meetings, Google Classroom for assignments, and Google Doc for formative tests. Limited facilities and children's ability to use the application. Our current learning strategy is Powerpoint based learning. Students' understanding of concepts is not optimal. Students do not open reference books. Learning in our school sometimes links with local potential through observations around students' homes. We assigned them to observe the vegetation in the forest as they helped their parents work. For example, we asked them to observe the movements of the shy princess and its relationship to the concept of plant motion. In addition, there are several local potentials related to physics learning that have been empirically researched, for example the Bakar Batu culture, the Malind tribe tradition, and building houses towards the north-south cardinal directions. This local potential is closely related to the concept of temperature and heat (Bakar Batu) and the concept of momentum and impulse (fishermen in Papua who are rowing their boats on Lake Sentani). Competency skills can be built from local potential." - Teacher from SMP N 5 Jayapura

Educator from SMA Pembangunan $V$ Yappis said that physics learning in the new normal era uses a combination of online and offline learning strategies.

"Our learning has been ineffective since the outbreak hit. We use observation-based learning strategies through demonstrations and experiments as a learning method. However, once there was COVID-19, we conducted online learning for six months. Towards the new normal, we tried to combine online and offline learning with an online percentage of $80 \%$ and an offline percentage of $20 \%$. We only hold offline when students submit assignments or take exams because we use paper tests. Not all of our students are skilled in using the internet and the internet network here often goes out due to blackouts. If we use full online learning, we think the results will be far from optimal. Even so, online learning does not dampen the enthusiasm of students in following physics learning when new normal. Contextually, we often assign students to observe indigenous Papuan cultures passed down from generation to generation in their families or areas to become reports with project-based learning. Then we discussed the results of the report in class." - Teacher from SMA Pembangunan V Yappis

Educators from the Universitas Cendrawasih answered that physics learning in the new normal era used blended learning as learning method.

"Scientific observations are carried out in a virtual laboratory. We refer to many interactive applications in online courses on the internet, for example, Phet Edu. Obstacles in learning that has more online processes are the problem of device ownership, whether there is an internet connection or not, and student motivation. We have met students in the first year and provided a conceptual flowchart of physics because the new generation did not come face to face because of the pandemic. However, from the start we emphasized that learning will be more online. Students then make efforts to borrow and even buy internet devices and data packages to participate in the learning. They are able to conclude the conceptual framework of physics obtained and understand the learning objectives well. Thus, the understanding of the concepts and enthusiasm of our students is quite high. We organize contextual learning. Our students are given the task to research the local culture that exists in Papua, for example, science in the Malind, Mingkuen, and Kuak tribes. This will stimulate their physics 
conceptual framework through the perceptions of their previous education levels. From this project, we find cases of misconceptions in physics. Local potential can be used to enhance physics learning resources and as a diagnostic tool for student understanding of concepts." - Lecturer from Universitas Cendrawasih

The majority of the answers through interviews found that educators in Papua, have the same obstacles; devices and internet connections during learning are not optimal. Respondents also answered that physics learning in the new normal era used a combination of online and offline strategies.

\section{Results on Direct Observation of Physics Learning During New Normal Era}

Researchers had participated in online physics learning in the new normal era with respondents from SMP N 5 Jayapura, SMA Pembangunan V Yappis, and Universitas Cendrawasih. Figure 1 shows the frequency of students taking online classes in physics learning.

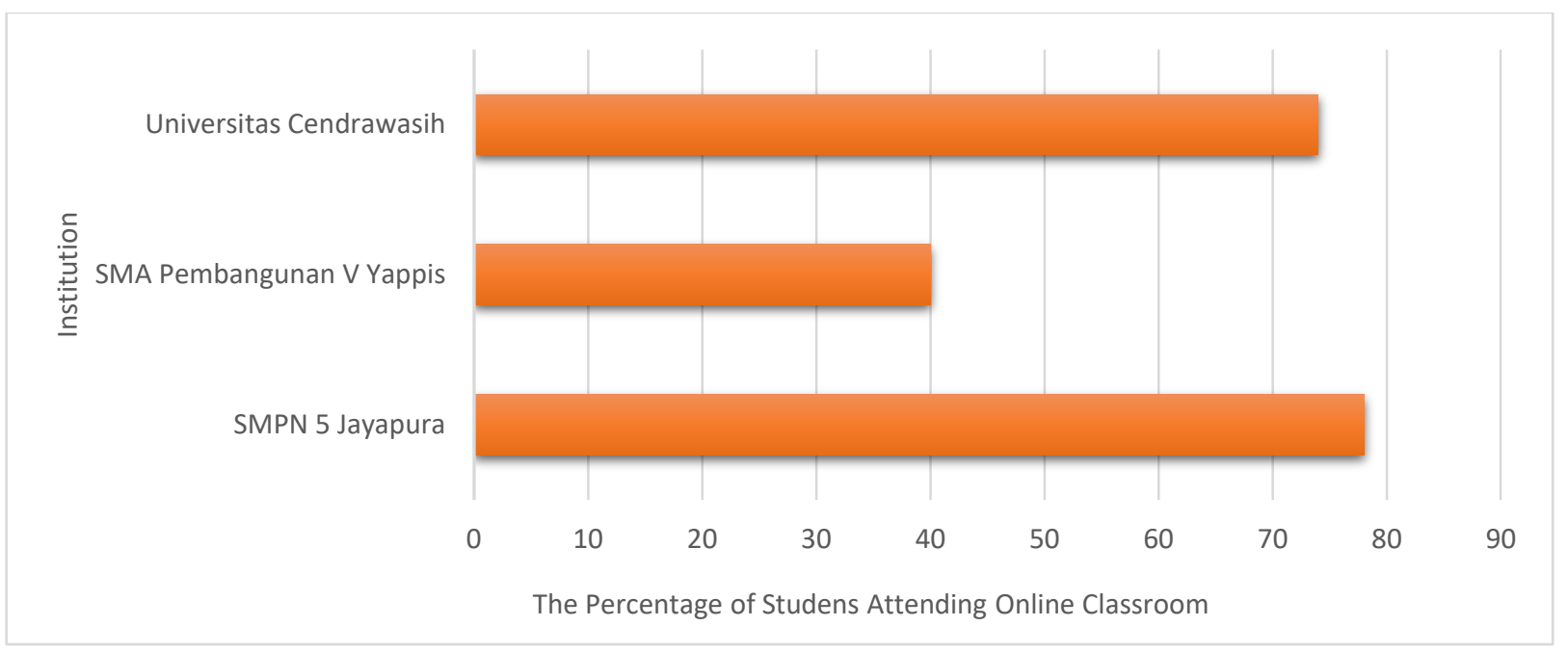

Figure 1. The Frequency of Students Attending the Online Classroom

The number of students in the sample class who came from SMP N 5 Jayapura was 29 and who took online learning during the observation process was $22(78 \%)$. The number of students in the sample class from SMA Pembangunan V Yappis who took online physics learning during the observation process was $40 \%$. The number of students in the sample class who came from Universitas Cendrawasih who took online physics learning during the observation process was $74 \%$. The learning process is quite conducive. There were students whose attention is good and there are students who didn't pay much attention to learning physics because they were bored. Some students turned on the camera and some turned off the camera.

\section{Designing the Plan of Physics Learning Based on Local Potential During New Normal Era}

Learning applied in Indonesia from elementary school to undergraduate level generally uses face-toface or direct learning methods (Rusydiyah et al., 2021). There is no question that the complexity of the natural system and its corresponding scientific problems necessitate interdisciplinary understanding informed by multiple disciplinary background during pandemic situation (You, 2017). Based on the results we found in questionnaires, interviews, and observations, there were several problems that became the focus and main core of learning physics in the new normal era. First, the constraints of having adequate devices and internet connections are still not available to all students according to the findings we got during the interview. This makes not all students able to take part in physics learning during online learning activities. Local potential can be a solution to this problem because some educators claim to have used local potential as a source of contextual learning (Betaubun, 2019; Hermino, 2016; Tanujaya et al., 2017). However, educators have not integrated local potential as a physics learning strategy during the online new normal era. All educators as interview respondents answered that they needed a solution for the device, internet connection, and the accuracy of the weight of online and offline learning and a combination of both. The learning situation during pandemic had teacher to elaborate their learning barrier. It is in line with previous study on chapter Newton's law material (Saregar et al., 2020). Thus, learning media has a very important role, therefore the media in learning has a function as a tool in the teaching and learning process to engage students to be active in learning in pandemic era using internet connection (Ningsih \& Jha, 2021). 
Second, the findings obtained by the researchers through questions on the questionnaire. In the discussion of learning strategies, almost all respondents responded that physics learning was carried out using a combination of online and offline strategies. The combination of online and offline learning can be called blended learning (Graham, 2006; Oliver \& Trigwell, 2005; Osguthorpe \& Graham, 2003). The problem in the form of low efficiency of the learning strategy used is the number two indicator that needs to be found a solution. The number one indicator, the effectiveness of online physics learning in the new normal era, gets the most number of answers in the "low" category. Based on these findings, the problem of ineffectiveness of online learning was the biggest obstacle for educators and students during the new normal era. This should be a concern to seek an immediate solution because the physics concepts being learned are never complete. Even so, students still have good attention, number of absences, and understanding of physics concepts during online physics learning. The combination of blended learning with local potential is expected to be a solution to this problem because students are directed to explore their respective local potentials (Ince, 2018). Educators will later integrate their findings with original science concepts (Khabibah, 2017). This is the basis for learning physics based on local potential. Students are more active than just sitting and paying attention to the Powerpoint slides that the educator displays on the screen of the device and the internet.

Third, the results of observations show that students have a great interest in learning physics online in the new normal era. Many students take part in learning physics by trying to borrow or buy a device in the form of a laptop and access to the internet in the form of data packages or wifi installation. The majority of students' enthusiasm is also good even though there are some students who turn off the camera while learning. This is the same as conventional learning problems (Astuti \& Bhakti, 2018; Diani \& Syarlisjiswan, 2018; Nurhidayati et al., 2019). If students do not have a big share in learning and only have a position as recipients of the material, over time students will feel bored (Macklem, 2015). Physics learning based on local potential is expected to be able to answer educators' concerns about this finding. Students will be directed to find and make essays related to local potential in their families and environment (Prasetyono \& Rakhmawati, 2019; Yuliana et al., 2017). Educators, through discussion, will provide good feedback in the form of integration of physics concepts that students find and original physics concepts through discussion. This is called concept confirmation through indigenous science. This is important to do so that physics learning is contextual to conduct in rural area (Ekici, 2016; Faulconer et al., 2018; Li et al., 2018).

Based on the findings from questionnaires, interviews, and observations, we designed a physics learning design plan based on local potential in the new normal era in Papua. The online and offline combination physics learning design is shown in Figure 2, while the physics learning design based on local potential in the new normal era is shown in Figure 3.

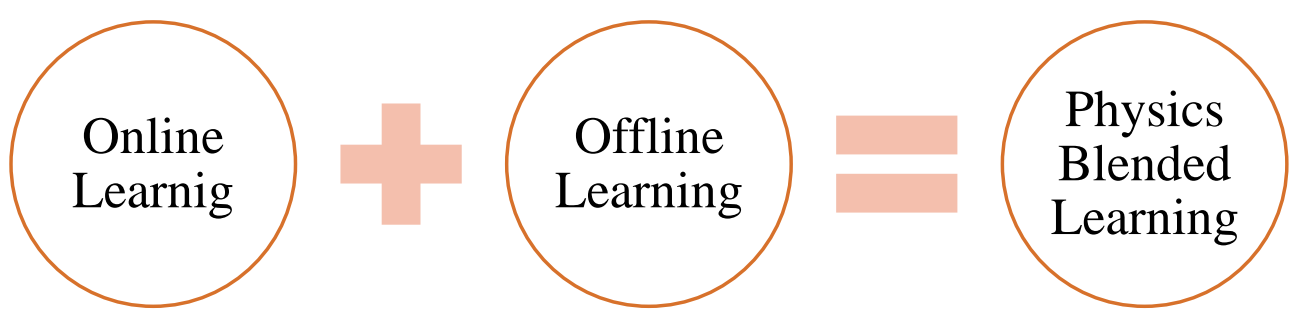

Figure 2. Designing Physics Learning through Blended Learning During New Normal Era 


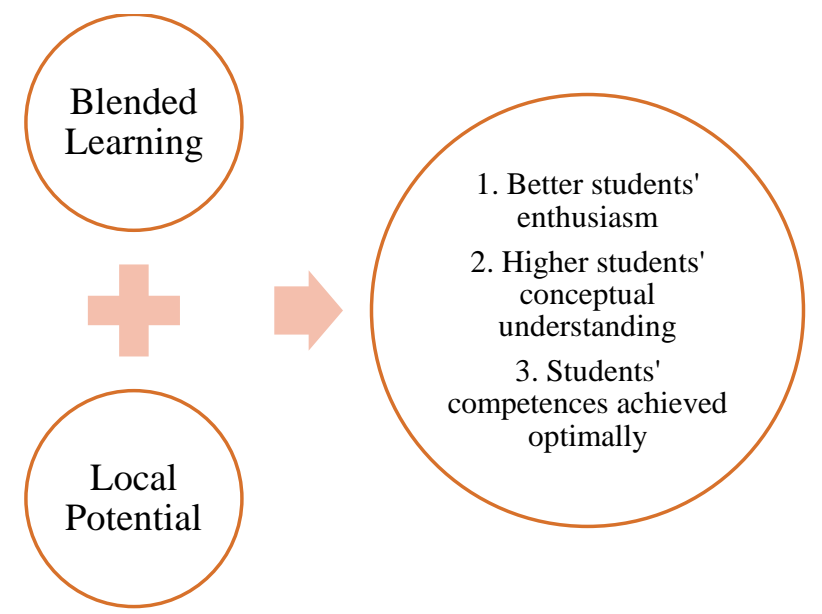

Figure 3. Designing Physics through Blended Learning Based on Local Potential

The feedback from educators about physics learning design based on local potential in the new normal era has had good results. Educators provide input on how the application of blended learning is combined with the foundation of local potential in Papua, so that students can learn contextual physics concepts based on local potential in the new normal era at home and the environment through their respective families and regions. This can be a solution if students are unable to attend online classes on time. They can do assignments from educators to observe local culture, local wisdom, and local potential related to physics concepts being discussed in class. The learning design in Figure 3 requires verification, validation, and reliability through small, medium, and large scale.

According to previous research, the most effective percentage of online learning and offline learning in blended learning is $25 \%$ and $75 \%$ (Adi \& Fathoni, 2020; Kintu et al., 2017; Osman \& Hamzah, 2017). There are more offline meetings than online meetings during learning so that students will get an optimal understanding of the concept and experience less boredom while learning. However, the new normal era did not allow face-to-face meetings in class because the number of students in one class exceeded 5 people; which is the limit on the number of people interacting in a closed room at one time according to government health protocols. This percentage is suggested to be reversed with the number of face-to-face meetings of $25 \%$ and online meetings of 75\% (Atiqoh, 2020; Bohmer et al., 2020; Buheji \& Buheji, 2020; Fitriyani et al., 2020; Sadikin \& Hamidah, 2020). During the online meeting, if there are students who are constrained by an internet connection or device, then students may be directed to observe the local potential that exists in their family or environment. The key to learning physics based on local potential during the new normal era is the flexibility of learning for students, so that learning physics does not burden students during the new normal era through online and offline learning.

The correlation between local culture or local potential with the quality of education has been studied since the past decades. There is a research determining the learning materials integrating local culture into a guided learning model. The local culture in this study was adapted to the local culture of the students, namely the Batak Toba. Based on the results of the study, it was suggested that mathematics teachers make an effort qualified learning materials and integrate local culture in mathematics learning (Simamora et al., 2018). Other research also produced an Android-assisted mobile physics-learning program to increase high school students' abilities in creative thinking and problem solving. The learning materials were based on local batik-making culture and included physics material on heat. The results showed that Android-assisted mobile physics learning, supported by local batik culture, is feasible for high school physics learning (Shabrina \& Kuswanto, 2018). Thus, the integrated local culture in learning can improve the quality of education.

\section{CONCLUSION}

The results of the study found that the physics learning design based on local potential in the new normal era can be an alternative for teaching physics concepts contextually. Students can observe the surrounding environment related to local customary culture which is indigenous science and educators represent the report in the form of a connection between the concept of science and local culture because during the pandemic students are more at home and going into the forest to help their parents. This research is expected to be the first step to improve the effectiveness of physics learning in rural areas such as Papua 
in the new normal era. Local potential is an important parameter because students are not always with educators during physics learning in one room. Sometimes students prefer not to take physics lessons and help their parents to the forest. With the existence of physics learning based on local potential, educators can design contextual physics learning by assigning students to do direct observations on the local culture around their place of residence.

\section{AUTHOR'S CONTIBUTION}

The first author conducted the pilot study and main research in various academic institution in Jayapura, Papua. The second author helped to adapt and modify the questionnaires and interview questions. The third author collaborated in analyzing the data and writing the article.

\section{ACKNOWLEDGEMENT}

Authors want to send their gratitude to the respondents; teacher and students who gave their consent and joined this research from the beginning of study. The authors acknowledge these academic institutions: SMP N 5 Jayapura, SMA Pembangunan V Yappis, and Universitas Cenderawasih for their permission and support. Also, the authors want to give their appreciation for Universitas Cenderawasih, UIN Sunan Kalijaga, and Universitas Lampung for their grant and support toward this study.

\section{REFERENCES}

Abonyi, O. S., Achimugu, L., \& Njoku, M. (2014). Innovations in Science and Technology Education: A case for ethnoscience based science classrooms. International Journal of Scientific and Engineering Research, 5(1), 52-56.

Adi, S., \& Fathoni, A. (2020). Blended Learning Analysis for Sports Schools in Indonesia.

Akmam, A., Anshari, R., Amir, H., Jalinus, N., \& Amran, A. (2018). Influence of learning strategy of cognitive conflict on student misconception in computational physics course. IOP Conf. Series: Materials Science and Engineering, 335, 1-7.

Alsmadi, M. K., Al-Marashdeh, I., Alzaqebah, M., Jaradat, G., Alghamdi, F. A., Mohammad, R. M. A., Alshabanah, M., Alrajhi, D., Alkhaldi, H., \& Aldhafferi, N. (2021). Digitalization of learning in Saudi Arabia during the COVID-19 outbreak: A survey. Informatics in Medicine Unlocked, 100632.

Annisa, S. A., Lesmono, A. D., \& Yushardi, Y. (2020). Comic-Based Module Development Andro-Web to Improve Problem Solving Ability in Physics in High School Students. Berkala Ilmiah Pendidikan Fisika, 8(1), 40. https://doi.org/10.20527/bipf.v8i1.7641

Astuti, I. A. D., \& Bhakti, Y. B. (2018). Interactive learning multimedia based Microsoft excel on the temperature and heat. Unnes Science Education Journal, $7(1)$.

Atiqoh, L. N. (2020). Respon Orang Tua Terhadap Pembelajaran Daring Pada Masa Pandemi Covid-19. Thufuli: Jurnal Ilmiah Pendidikan Islam Anak Usia Dini, 2(1), 45-52.

Atmojo, S. E. (2015). Learning which oriented on local wisdom to grow a positive appreciation of batik jumputan (ikat celup method). Jurnal Pendidikan IPA Indonesia, 4(1), 48-55.

Azlan, C. A., Wong, J. H. D., Tan, L. K., Muhammad Shahrun, M. S. N., Ung, N. M., Pallath, V., Tan, C. P. L., Yeong, C. H., \& Ng, K. H. (2020). Teaching and learning of postgraduate medical physics using Internet-based e-learning during the COVID-19 pandemic - A case study from Malaysia. Physica Medica, 80, 10-16. https://doi.org/10.1016/J.EJMP.2020.10.002

Behrendt, H., Dahncke, H., Duit, R., Gräber, W., Komorek, M., Kross, A., \& Reiska, P. (2001). Research in science education-Past, present, and future. Springer Science \& Business Media.

Betaubun, P. (2019). Papua contextual science curriculum contains with indigenous science (Ethnopedagogy study at Malind Tribe Merauke). Technology, 10(02), 1994-2000.

Bieber, T., \& Martens, K. (2011). The OECD PISA study as a soft power in education? Lessons from Switzerland and the US. European Journal of Education, 46(1), 101-116. 
Bohmer, R., Shand, J., Allwood, D., Wragg, A., \& Mountford, J. (2020). Learning systems: Managing uncertainty in the new normal of COVID-19. NEJM Catalyst Innovations in Care Delivery, 1(4).

Budiarti, I S, Suparmi, A., Sarwanto, S., \& Harjana, H. (2020). Effectiveness of Generation, Evaluation, and Modification-Cooperative Learning (Gem-Cl) Model Selaras Bakar Batu Cultural Practice in Papua. Jurnal Pendidikan IPA Indonesia, 9(1).

Budiarti, I. S. (2017). Potensi budaya bakar batu dalam pembelajaran fisika. Prosiding SNPF (Seminar Nasional Pendidikan Fisika), 22-25.

Budiarti, I S, Suparmi, A., Sarwanto, S., \& Harjana, H. (2017). Students' conceptual understanding consistency of heat and temperature. Journal of Physics: Conf. Series, 795, 012051. https://doi.org/10.1088/1742-6596/755/1/011001

Buheji, M., \& Buheji, A. (2020). Planning Competency in the New Normal-Employability Competency in Post-COVID-19 Pandemic. International Journal of Human Resource Studies, 10(2), 237-251.

Chang-Tik, C. (2020). An analysis of discipline and personality in blended environments: Do they interact differently in the teaching, cognitive, and social presences? Canadian Journal of Learning and Technology, 46(1), 1-19. https://doi.org/10.21432/cjlt27883

Dewi, C. A., Khery, Y., \& Erna, M. (2019). An ethnoscience study in chemistry learning to develop scientific literacy. Jurnal Pendidikan IPA Indonesia, 8(2), 279-287. https://doi.org/10.15294/jpii.v8i2.19261

Diani, R., \& Syarlisjiswan, M. R. (2018). Web-enhanced course based on problem-based learning (PBL): Development of interactive learning media for basic physics II. Jurnal Ilmiah Pendidikan Fisika AlBiruni, 7(1), 105.

Dwianto, A., Wilujeng, I., Prasetyo, Z. K., \& Suryadarma, I. G. P. (2017). The development of science domain based learning tool which is integrated with local wisdom to improve science process skill and scientific attitude. Jurnal Pendidikan IPA Indonesia, 6(1).

Ekici, E. (2016). “Why Do I Slog through the Physics?” Understanding High School Students' Difficulties in Learning Physics. Journal of Education and Practice, 7(7), 95-107.

Fasasi, R. A. (2017). Effects of ethnoscience instruction, school location, and parental educational status on learners' attitude towards science. International Journal of Science Education, 39(5), 548-564.

Faulconer, E. K., Griffith, J., Wood, B., Acharyya, S., \& Roberts, D. (2018). A comparison of online, video synchronous, and traditional learning modes for an introductory undergraduate physics course. Journal of Science Education and Technology, 27(5), 404-411.

Fitriah, L. (2019). Efektivitas Buku Ajar Fisika Dasar 1 Berintegrasi Imtak dan Kearifan Lokal Melalui Model Pengajaran Langsung. Berkala Ilmiah Pendidikan Fisika, 7(2), 82.

Fitriyani, Y., Fauzi, I., \& Sari, M. Z. (2020). Motivasi Belajar Mahasiswa Pada Pembelajaran Daring Selama Pandemik Covid-19. Jurnal Kependidikan: Jurnal Hasil Penelitian Dan Kajian Kepustakaan Di Bidang Pendidikan, Pengajaran Dan Pembelajaran, 6(2), 165-175.

Gong, J. W., Liu, H. C., You, X. Y., \& Yin, L. (2021). An integrated multi-criteria decision making approach with linguistic hesitant fuzzy sets for E-learning website evaluation and selection. Applied Soft Computing, 102.

Graham, C. R. (2006). Blended learning systems. The Handbook of Blended Learning: Global Perspectives, Local Designs, 3-21.

Guarte, J. M., \& Barrios, E. B. (2006). Estimation under purposive sampling. Communications in StatisticsSimulation and Computation, 35(2), 277-284.

Handhika, J., Fatmaryanti, S. D., Khasanah, N., \& Budiarti, I. S. (2020). Pembelajaran Sains di Era Akselerasi Digital. https://books.google.co.id/books?id=wBXmDwAAQBAJ

Hermino, A. (2016). The Effectiveness of Implementation School-Based Management in the Central Highlands of Papua Indonesia. International Journal of Education and Research, 4(10), 291-304.

Hiwatig, A. D. F. (2008). Ethno-Scientific Teaching Approach, Student Proficiency, and Attitude Toward Science and Ethnic Culture. Education Quarterly, 66(1).

Hoy, W. K., \& Miskel, C. G. (1987). Educational administration: Theory, research, and practice. Random House Trade. 
Hurrell, J. A., \& Albuquerque, U. P. (2012). Is ethnobotany an ecological science? Steps towards a complex ethnobotany. Ethnobiology and Conservation, 1.

Ibe, E., \& Nwosu, A. A. (2017). Effects of Ethnoscience and Traditional Laboratory Practical on Science Process Skills Acquisition of Secondary School Biology Students in Nigeria. British Journal of Multidisciplinary and Advanced Studies, 1(1), 35-46.

Ince, E. (2018). An Overview of Problem Solving Studies in Physics Education. Journal of Education and Learning, 7(4), 191-200.

Indrawardana, I. (2013). Kearifan Lokal Adat Masyarakat Sunda Dalam Hubungan Dengan Lingkungan Alam. Komunitas: International Journal of Indonesian Society and Culture, 4(1), 1-8. https://doi.org/10.15294/komunitas.v4i1.2390

Kaya, V. H., \& Elster, D. (2018). German Students' Environmental Literacy in Science Education Based on PISA Data. Science Education International, 29(2), 75-87.

Khabibah, E. N. (2017). The Effectiveness of Module Based on Discovery Learning to Increase Generic Science Skills. Journal of Education and Learning. https://doi.org/10.11591/edulearn.v11i2.6076

Kintu, M. J., Zhu, C., \& Kagambe, E. (2017). Blended learning effectiveness: the relationship between student characteristics, design features and outcomes. International Journal of Educational Technology in Higher Education, 14(1), 7.

Kurniawan, Y., Muliyani, R., \& Nassim, S. (2019). Digital story conceptual change oriented (DSCC) to reduce students' misconceptions in physics. Al-Biruni Journal of Physics Education/Jurnal Ilmiah Pendidikan Fisika Al-Biruni, 8(2), 211-220.

Li, J., Ye, H., Tang, Y., Zhou, Z., \& Hu, X. (2018). What Are the Effects of Self-Regulation Phases and Strategies for Chinese Students? A Meta-Analysis of Two Decades Research of the Association Between Self-Regulation and Academic Performance . In Frontiers in Psychology (Vol. 9, p. 2434). https://www.frontiersin.org/article/10.3389/fpsyg.2018.02434

Macklem, G. L. (2015). Boredom in the classroom: Addressing student motivation, self-regulation, and engagement in learning (Vol. 1). Springer.

Mardiana, N., \& Kuswanto, H. (2017). Android-assisted physics mobile learning to improve senior high school students' divergent thinking skills and physics HOTS. AIP Conference Proceedings, 1868(1), 70005 .

Miller, T., \& Edward, P. (2020). Winter / Hiver 2020 Online Learning: Practices , Perceptions, and Technology Apprentissage en ligne: Pratiques, perceptions et technologie. 46(1), 1-27.

Ningsih, T., \& Jha, G. K. (2021). Strengthening Student Competency in Making Social Science Learning Media , Social Science Development Courses. JIECR, 2(1), 1-6. https://doi.org/10.46843/jiecr.v2i1.23

Nurhidayati, N., Fauzia, S., \& Maknun, A. L. U. (2019). Arouse the Creativity of a Generation of Millenial Doctrines with the Media Learning Physics and Innovative Eco-Friendly. Proceeding International Conference on Science and Engineering, 2, 331-335.

Oliver, M., \& Trigwell, K. (2005). Can 'blended learning'be redeemed? E-Learning and Digital Media, 2(1), $17-26$.

Osguthorpe, R. T., \& Graham, C. R. (2003). Blended learning environments: Definitions and directions. Quarterly Review of Distance Education, 4(3), 227-233.

Osman, N., \& Hamzah, M. I. (2017). Student readiness in learning Arabic language based on blended learning. International Journal of Applied Linguistics and English Literature, 6(5), 83-89.

Patton, M. Q. (2014). Qualitative Research \& Evaluation Methods: Integrating Theory and Practice.

Prasetyono, P., \& Rakhmawati, Y. (2019). Gaduhan: Madurese Traditional Cattle Sharing Program in Economic and Social Perspective. Advances in Social Science, Education and Humanities Research, 363 (Icss), 24-27.

Rianti, S., Akhsan, H., \& Ismet, I. (2020). Development Modern Physics Digital Handout Based on Technology Literacy. Berkala Ilmiah Pendidikan Fisika, 8(1), 23. https://doi.org/10.20527/bipf.v8i1.7593

Risdianto, E., Dinissjah, M. J., \& Nirwana, M. K. (2020). The Effect of Ethno Science-Based Direct Instruction Learning Model in Physics Learning on Students' Critical Thinking Skill. Universal Journal of Educational Research, 8(2), 611-615. 
Rusydiyah, E. F., Virgiannada, H. R., Ridwan, M., \& Adhi, B. (2021). Clustering of Learning Media User Data During Covid-19 Pandemic Using K-Means Method Based on Multicultural Culture in Indonesia. JIECR, 2(2), 67-76. https://doi.org/10.46843/jiecr.v2i2.39

Sadikin, A., \& Hamidah, A. (2020). Pembelajaran Daring di Tengah Wabah Covid-19. Biodik, 6(2), 214-224.

Saregar, A., Mulyani, H., Anugrah, A., \& Ravanis, K. (2020). An Analysis of Epistemological Learning Barriers on Newton's Law Material in Engineering Class. JIECR, 1(2), 77-86.

Shabrina, \& Kuswanto, H. (2018). Android-assisted mobile physics learning through indonesian batik culture: Improving students' creative thinking and problem solving. International Journal of Instruction, 11(4), 287-302. https://doi.org/10.12973/iji.2018.11419a

Simamora, R. E., Saragih, S., \& Hasratuddin, H. (2018). Improving Students' Mathematical Problem Solving Ability and Self-Efficacy through Guided Discovery Learning in Local Culture Context. International Electronic Journal of Mathematics Education, 14(1), 61-72.

Singh, S., \& Hussain, S. Z. (2020). Mechanising E-learning for equiping start-up entrepreneurs. Materials Today: Proceedings, 37(Part 2), 2467-2469.

Sudarmin, S., Mursiti, S., \& Asih, A. G. (2018). The use of scientific direct instruction model with video learning of ethnoscience to improve students' critical thinking skills. Journal of Physics: Conference Series, 1006(1), 12011.

Suherman, A. (2014). Implementasi kurikulum baru tahun 2013 mata pelajaran pendidikan jasmani (studi deskriptif kualitatif pada SDN Cilengkrang). Mimbar Sekolah Dasar, 1(1), 71-76.

Sulistijo, S. H., Sukarmin, S., \& Sunarno, W. (2017). Physics Learning Using Inquiry-Student Team Achievement Division (ISTAD) and Guided Inquiry Models Viewed by Students Achievement Motivation. Jurnal Pendidikan IPA Indonesia, 6(1).

Tanujaya, B., Prahmana, R., \& Mumu, J. (2017). Mathematics instruction, problems, challenges, and opportunities: A case study in Manokwari regency, Indonesia.

Tongco, M. D. C. (2007). Purposive sampling as a tool for informant selection. Ethnobotany Research and Applications, 5, 147-158.

Trisniarti, M. D., Aminah, N. S., \& Sarwanto, S. (2020). Profile of senior high school students' misconception in physics using need-based analysis. Journal of Physics: Conference Series, 1567, 32072.

Utama, Y. J. (2017). Achieving Research University: Indonesian Case. IOP Conference Series: Earth and Environmental Science, 55(1), 12072.

Vanleeuwen, C. A., \& Belikov, O. (2020). Summer / été 2020 Institutional Perspectives on Faculty Development for Digital Education in Canada Perspectives institutionnelles sur le développement du corps professoral pour I' éducation numérique au Canada. 46(2).

Widana, I. W. (2020). The Effect of Digital Literacy on the Ability of Teachers to Develop HOTS-based Assessment. Journal of Physics: Conference Series, 1503(1), 12045.

Winarti, W., \& Budiarti, I. S. (2020). Diagnostik Konsepsi Siswa pada Materi Suhu dan Kalor. Jurnal Ilmu Pendidikan Indonesia, 8(3), 136-146.

You, H. S. (2017). Why Teach Science with an Interdisciplinary Approach: History, Trends, and Conceptual Frameworks. Journal of Education and Learning, 6(4), 66-77.

Yuliana, Sriyati, S., \& Sanjaya, Y. (2017). Local wisdom of Ngata Toro community in utilizing forest resources as a learning source of biology. AIP Conference Proceedings, 1868(August). https://doi.org/10.1063/1.4995217

Yustina, Y., Halim, L., \& Mahadi, I. (2020). The Effect of "Fish Diversity" Book in Kampar District on the Learning Motivation and Obstacles of Kampar High School Students through Online Learning during the COVID-19 Period. Journal of Innovation in Educational and Cultural Research, 1(1), 7-14. https://doi.org/10.46843/jiecr.v1i1.2 